\title{
A ATUAÇÃO POLÍTICA DO SUPREMO TRIBUNAL FEDERAL: JURISDIÇÃO CONSTITUCIONAL OU ATIVISMO JUDICIAL?
}

\author{
Juliana Gonçalves de Oliveira ${ }^{41}$ \\ Rafael Fonseca Ferreira ${ }^{42}$
}

Recebido em: 16/12/2017

Aprovado em: 13/02/2018

\begin{abstract}
RESUMO
Com o presente artigo, pretende-se, de modo geral, analisar, dentro da relação entre Política e Direito, a atuação política que o Supremo Tribunal Federal tem tido nos últimos tempos, observando aspectos que podem levar a constatar se esta atuação se encontra dentre os parâmetros da jurisdição constitucional ou se pode ser considerada como uma posição ativista dos julgadores. Dentre os objetivos específicos da pesquisa, pretende-se, de início, abordar a relação de dessemelhança e de dependência existente entre o Direito e a Política, para, na sequência, verificar como a Constituição Federal de 1988 e a jurisdição constitucional alterou tal relação. Ainda, se tem o intuito de abordar os institutos da jurisdição constitucional e do ativismo judicial, estabelecendo uma distinção entre ambos para que seja possível averiguar se a atuação política do Supremo Tribunal Federal pode ser considerada como um reflexo natural da jurisdição constitucional e da maior autonomia que o constituinte de 1988 concedeu ao Poder Judiciário ou caracteriza-se como uma atuação discricionária, típica do instituto do ativismo judicial. Para tanto, a base metodológica desta pesquisa é a fenomenológica-hermenêutica, que vai além de uma análise exclusivamente semântica da linguagem, busca superar os pré-conceitos do senso comum, para fazer uma reconstrução histórica tendo como base uma teoria crítica.
\end{abstract}

Palavras-chave: Atuação política. Jurisdição constitucional. Ativismo. Autonomia do Direito

\section{INTRODUÇÃO}

\footnotetext{
${ }^{41}$ Mestranda em Direito e Justiça Social pela Universidade Federal do Rio Grande - FURG. Pós-graduada em Direito Constitucional e em Direito e Processo do Trabalho pela Universidade Anhanguera UNIDERP/LFG. Advogada.

${ }^{42}$ Doutor e Mestre em Direito pela Universidade do Vale do Rio dos Sinos (UNISINOS). Especialista em Comércio Exterior e Relações Internacionais pela Universidade de Caxias do Sul (UCS). Professor da Universidade Federal do Rio Grande (FURG). Advogado. Membro da Associação Brasileira de Direito Processual Constitucional (ABDPC).
} 
Partindo da premissa histórica de que no Brasil, tanto o Direito, quanto o Judiciário sempre foram fragilizados e instrumentalizados em face dos Poderes Políticos, a Constituição Federal de 1988, além de redemocratizar o país, trouxe a possibilidade de uma autonomia do Direito, onde as decisões judiciais não são mais limitadas à vontade política, mas sim, o único limite, para qualquer um dos três Poderes da União é a própria Constituição e suas normas.

Tendo em vista que o constituinte de 1988 trouxe a previsão da jurisdição constitucional e dispôs o Supremo Tribunal Federal como um tipo de Corte Constitucional, com legitimidade para fazer o controle de constitucionalidade tem-se que o objetivo geral do presente artigo é analisar a atuação do Supremo Tribunal Federal tida como Política, para que se possa constatar se tal atuação encontra-se dentro dos parâmetros e limites (explícitos e implícitos) estipulados pela própria Constituição, ou se as decisões da Suprema Corte brasileira têm extrapolado certos limites, adentrando em discricionariedades típicas do ativismo judicial.

Dentre os objetivos específicos, que estão delineados nos capítulos deste artigo, inicialmente se espera analisar, brevemente, a relação existente entre Direito e Política no âmbito do Direito Constitucional brasileiro, constatando a evolução desta relação no passar dos anos. Pretende-se, também, demonstrar as semelhanças e as fundamentais diferenças entre os fenômenos da judicialização da política e do ativismo judicial, atestando a íntima relação da judicialização com o Constitucionalismo Contemporâneo, vez que a Constituição Federal de 1988 foi a primeira a prever, no Brasil, a incidência da jurisdição constitucional, bem como se pretende expor o nexo do atual crescente ativismo judicial com as discricionariedades praticadas pelos magistrados e demonstrar algumas críticas ao fenômeno do ativismo, demonstrando como este traz à tona um problema democrático diante do Princípio da separação dos poderes. Ainda, se intenciona abordar a algumas decisões do Supremo Tribunal Federal que podem ser entendidas como decisões políticas, para assim verificar se tais decisões se enquadram como decisões que obedecem aos parâmetros da jurisdição constitucional ou se podem ser tidas como decisões ativistas e discricionárias.

O trabalho se justifica no âmbito jurídico/social, pelo fato de cada vez mais o Supremo Tribunal Federal fazer o papel de tribunal político, decidindo sobre temas de intensa relevância social, bem como, pelo fato da judicialização da política ser um instituto em intenso crescimento no judiciário brasileiro. Já no âmbito acadêmico, justifica-se, pois, quando se constata que decisões políticas em um órgão jurídico estão se tornando rotina, e o deslocamento de competência entre os poderes pode colocar em xeque a própria democracia, 
cabe à doutrina, em especial à doutrina crítica, exercer seu papel na defesa das premissas constitucionais.

A base metodológica do presente trabalho é a fenomenológica-hermenêutica, que vai além de uma análise exclusivamente semântica da linguagem, busca superar os pré-conceitos do senso comum, para fazer uma reconstrução histórica tendo como base uma teoria crítica. Quanto ao procedimento, a metodologia é essencialmente monográfico-crítica e a técnica empregada será bibliográfica e jurisprudencial baseada na análise de livros, artigos científicos e decisões do Supremo Tribunal Federal.

\section{A RELAÇÃo ENTRE DIREITO E POLÍTICA}

No decorrer dos anos, a história brasileira acerca da relação existente entre Direito e Política foi marcada pela fragilidade, mais precisamente, por uma fragilização do Direito. Desde o Império e até a redemocratização do país, em 1988, o Brasil sofreu com atuações do Executivo que privilegiavam suas vontades políticas em desprezo aos ideais democráticos e constitucionais, ou seja, a Política não se submetia a um controle judicial, restando ao Direito apenas um papel secundário, de legitimar os atos dos Poderes Políticos.

Historicamente o Brasil foi falho em limitar o poder político e em garantir a supremacia das normas constitucionais, isso se deu, porque durante décadas o Poder Judiciário careceu de autonomia funcional, sofrendo diversas interferências por parte dos demais poderes. As inúmeras interferências políticas no Judiciário acabam colaborando para que governos autoritários tomassem o poder e nele se mantivessem por anos, "em vez de um poder político submetido à Constituição, o que realmente predominou foi a sobreposição de um domínio estamental contrário ao Direito, corroborando por uma atuação institucional inexpressiva por parte do Poder Judiciário" (STRECK; TASSINARI; LIMA, 2013, p. 741).

Esta instrumentalização do Direito, ao lado de um constante controle político do Poder Judiciário, mostrou-se como causa e consequência direta da falta de uma autêntica jurisdição constitucional. Quando presente nos textos constitucionais anteriores à 1988, a jurisdição constitucional se deu apenas em seu aspecto forma, o que impossibilitou o surgimento de uma ordem constitucional verdadeiramente democrática, baseada na tripartição de Poderes (STRECK; TASSINARI; LIMA, 2013, p. 745).

É interessante salientar que, além de fazer com que o Poder Judiciário se tornasse destituído de autonomia funcional, a ausência de uma autêntica jurisdição constitucional, 
contribuiu fortemente para o enfraquecimento da Constituição durante os anos em que o Brasil foi governado por regimes não democráticos e/ou autoritários. Apenas com a Constituição de 1988 o Poder Judiciário passou a ocupar um papel de maior importância frente aos demais poderes da União, através da consolidação da jurisdição constitucional, do controle concentrado de constitucionalidade e da real autonomia entre os poderes da União.

A Constituição Federal de 1988 faz a ligação entre Política e Direito, distinguindo os atos de administrar, legislar e julgar, bem como, distribuindo-os como atribuições dos Poderes constituídos. A independência do Poder Judiciário busca proteger a atuação dos juízes das ameaças políticas, bem como, a supremacia da Constituição visa legitimar e limitar os Poderes Políticos. A transição de um Estado Autoritário para um Estado Democrático de Direito trouxe consigo o aumento do controle dos atos políticos, transferindo ao Supremo Tribunal Federal o papel institucional de guardião da Constituição, com isso, o Direito passou, de certo modo, a se sobrepor às decisões políticas do Poder Executivo e às decisões majoritárias do Poder Legilativo, já que, há uma supremacia constitucional que deve ser observada em tais decisões e para tanto, o Supremo Tribunal Federal é o órgão legítimo para aferir se tais decisões estão de acordo ou não com as normas constitucionais.

Dentro deste contexto nota-se que Direito e Política são elementos fundamentais, tanto para a judicialização da política, quanto para a própria noção de constitucionalismo. Tanto que, Clarissa Tassinari (2013, p. 28) explica que "o constitucionalismo pode ser definido como uma tentativa jurídica (Direito) de oferecer limites para o poder político (Política), o que se dá por meio das Constituições”, assim, em que pese a relação entre Direito e Política ser de interdependência, o fato da Constituição oferecer os limites garante que tal relação não seja fundada em decisionismos.

De fato, dentro do contexto de um Estado Democrático de Direito é fundamental que o Direito e a Política ocupem lugares distintos, pois na Política "vigoram a soberania popular e o princípio majoritário", ou seja "o domínio da vontade", já no Direito "vigora o primado da lei (the rule of law) e do respeito aos direitos fundamentais", isto é, "o domínio da razão" (BARROSO, 2012b, p. 378).

Todavia, em que pese o fato de o Direito e a Política possuírem espaços diversos em um Estado Democrático, a linha que os separa é demasiadamente tênue e por vezes ambos até mesmo se confundem. Afinal, o "direito é, na verdade, um dos principais produtos da política", e quando o Poder Judiciário, mais precisamente, o Supremo Tribunal Federal, decide sobre a constitucionalidade de leis, com decisões vinculantes, utiliza-se de uma “supremacia judicial quanto à determinação do que é o direito, envolvendo, por evidente, o 
exercício de um poder político, com todas as suas implicações para a legitimidade democrática”. (BARROSO, 2012b, p. 378 e 385).

Tendo em vista a visão clássica de separação de poderes, originalmente, o Judiciário ocupava a posição mais fraca dentre os Poderes da União. Porém nos últimos tempos, tem se observado um frequente deslocamento de poder das instituições representativas para as judiciais. Com isso, percebe-se que a autonomia do Direito, pretendida pelo constituinte de 1988 acabou dando lugar a um novo tipo de regime político, o qual se tem chamado de "juristocracia". 43

O advento do Estado Democrático de Direito traz consigo a concepção de Direito e Política como conceitos diferentes, porém indissociáveis, entretanto, “a atuação do Judiciário, pela via do controle de constitucionalidade, estaria comprometida em possibilitar tal mudança, delimitando, por critérios jurídicos, os limites da Política" (STRECK; TASSINARI; LIMA, 2013, p. 739).

Assim, a autonomia do Direito, tão almejada após anos de governos autoritários e de fragilização do Poder Judiciário, acabou não sendo concretizada de maneira adequada no Estado Democrático brasileiro, para tanto, tendo em vista o grau de judicialização existente no Brasil, pode-se dizer que o país atingiu a "política pura" (HIRSCHL, 2009, p. 140). Em verdade, a existência de uma intensa judicialização da Política é apenas uma contradição secundária:

A grande questão não é o quanto de judicialização, mas como as questões judicializadas devem ser decididas e, nesse ponto, o problema central é a propagação da tese favorável ao ativismo judicial, porque ela permite que, novamente, a Política fragilize o Direito de modo institucionalizado (STRECK; TASSINARI; LIMA, 2013, p. 739-740).

Com isso, percebe-se a questão primordial fruto da autonomia que o Poder Judiciário conquistou após a Constituição Federal de 1988, qual seja: se a atuação política do Judiciário, principalmente do Supremo Tribunal Federal, tem se mostrado como um fruto natural da jurisdição constitucional ou mostra-se como ativista e eivada de discricionariedade.

\section{JURISDIÇÃO CONSTITUCIONAL E ATIVISMO JUDICIAL}

\footnotetext{
${ }^{43}$ O termo "juristocracia" (juristocracy) foi cunhado pelo cientista político canadense Ran Hirschl, em sua obra "Towards Juristocracy". Para o autor juristocracia seria o deslocamento do poder político para o Judiciário, que se dá quanto as elites políticas, econômicas e sociais transferem poder ao Judiciário, de forma voluntária, quando ameaçadas de perder a hegemonia na esfera política. Para um melhor entendimento sobre o tema, ver: HIRSCHL, Ran. Towards juristocracy: the origins and consequences of the new constitutionalism. Cambridge: Harvard University Press, 2007.
} 
Em que pese o Constitucionalismo Contemporâneo ${ }^{44}$, em um contexto global, tenha se iniciado imediatamente no segundo pós-guerra, no Brasil, só se começou a debater temas relativos a este com a redemocratização do país, ou seja, com a Constituição Federal de 1988. $\mathrm{O}$ atraso constitucional vivido no Brasil, devido ao período ditatorial, não se deu apenas na constitucionalização dos direitos humanos, mas em diversos campos, no que tange à jurisdição constitucional, está somente foi prevista no Brasil pelo constituinte de 1988, que previu expressamente a possibilidade de revisões judiciais dos atos tomados pelos demais poderes em face às disposições constitucionais. Sendo que, em países desenvolvidos, como por exemplo, nos Estados Unidos, tal tema já é corriqueiro há aproximadamente $200 \operatorname{anos}^{45}$.

Apesar de ambos países tratarem do tema, quase dois séculos de história, bem como, diversas tradições jurídicas e sociais os separam, havendo uma enorme diferença entre as atuações do Judiciário nos Estados Unidos e no Brasil, este, mais jovem, é progressista, focado na alteração do texto constitucional por meio do Poder Judiciário, já aquele, mais tradicional, é conservador, mantendo uma postura não interventiva. (TASSINARI, 2013)

Desde logo, percebe-se que no Brasil, formou-se uma cultura pró-ativismo, onde por várias vezes se considera, erroneamente, que uma postura ativista do juiz é uma característica inerente à jurisdição, isso se dá, justamente pela falta do debate acadêmico sobre o tema.

Assim, necessário expor, brevemente, algumas considerações sobre a jurisdição constitucional na Constituição brasileira, bem como sobre a discricionariedade dos julgadores e a questão do ativismo judicial.

\subsection{A judicialização no contexto do constitucionalismo contemporâneo brasileiro}

O Constitucionalismo Contemporâneo começou a se formar, na grande maioria dos países desenvolvidos, a partir do segundo pós-guerra Mundial, tendo sido incorporado, no Brasil, apenas pela Constituição Federal de 1988. Redimensionou a prática política-jurídica,

\footnotetext{
${ }^{44}$ A expressão "Constitucionalismo Contemporâneo" foi cunhada pela primeira vez por Lenio Luiz Streck em sua obra "Verdade e Consenso", para tanto o autor ressaltou que "a partir de agora, passarei a nominar Constitucionalismo Contemporâneo (com iniciais maiúsculas) o movimento que desaguou nas Constituições do segundo pós-guerra e que ainda está presente em nosso contexto atual, para evitar os mal-entendidos que permeiam o termo neoconstitucionalismo" (STRECK, 2011, p. 37).

${ }^{45}$ Nos Estados Unidos da América os debates relativos ao tema da jurisdição constitucional surgiram em meados do ano de 1803, a partir do memorável caso Marbury vs. Madison, onde deu-se a primeira decisão de controle de constitucionalidade de atos do Congresso, mesmo sem que houvesse previsão expressa na Constituição para tanto.
} 
com o advento do Estado Democrático de Direito, repercutindo tanto na teoria do Estado quanto na da Constituição.

Em que pesem as evoluções que a Constituição de 1988 trouxe no campo da democracia e da positivação dos direitos e garantias fundamentais, ainda temos um enorme abismo a ser preenchido quando se trata de pensamento crítico, nas palavras de Rafael Fonseca Ferreira (2016, p. 13) "ainda é preciso pavimentar o caminho para que se possa operar uma transformação no pensamento jurídico e político ante a herança autoritária/arbitrária que permeia o imaginário dominante".

O advento do Constitucionalismo Contemporâneo causou uma verdadeira revolução na Teoria do Direito, reformulando a teoria das fontes e consolidando a supremacia da Constituição, que se sobrepôs à supremacia da lei, assim, a teoria da norma, por meio da normatividade dos princípios e da teoria da interpretação tem o intuito de proteger a Constituição de ativismos e de discricionariedades. (STRECK, 2011) Desse modo, temos que "constitucionalismo pode ser concebido como um movimento teórico jurídico-político em que se busca limitar o exercício do Poder a partir da concepção de mecanismos aptos a gerar e garantir o exercício da cidadania” (STRECK, 2011, p. 37).

Com a promulgação de uma nova Carta constitucional, que trouxe um novo contexto social e democrático houve um "deslocamento do polo de tensão" que saiu do Executivo e voltou-se ao Judiciário, precisamente, tais mudanças constitucionais propiciaram a ocorrência do fenômeno da judicialização da política. Para tanto, nas palavras de Lenio Streck:

\begin{abstract}
Em síntese, é a situação hermenêutica instaurada a partir do segundo pós-guerra que proporciona o fortalecimento da jurisdição (constitucional), não somente pelo caráter hermenêutico que assume direito, em uma fase pós-positivista e de superação do paradigma da filosofia da consciência, mas também pela força normativa dos textos constitucionais e pela equação que se forma a partir da inércia na execução de políticas públicas e na deficiente regulamentação legislativa de direitos previstos nas Constituições. É nisso que reside o que se pode denominar de deslocamento do polo de tensão dos demais poderes em direção ao Judiciário. (STRECK, 2011, p. 190).
\end{abstract}

Luís Roberto Barroso (2012a, p. 27) argumenta a expansão da atuação do Judiciário na tentativa de suprir as omissões dos outros Poderes vem sendo alavancada por uma "crise de representatividade, legitimidade e funcionalidade", tal crise também faz com que o Poder Executivo se utilize de maneira excessiva das medidas provisórias, o que, também fomenta a atuação do judiciário, que é provocado a verificar a constitucionalidade de tais medidas. Nessa ótica, alerta-se para o fato de que: 
A expansão do Judiciário não deve desviar a atenção da real disfunção que aflige a democracia brasileira: a crise de representatividade, legitimidade e funcionalidade do Poder Legislativo. Precisamos de reforma política. E essa não pode ser feita por juízes (BARROSO, 2012a, p. 32).

Inevitavelmente, a jurisdição constitucional se fortaleceu com a fase pós-positivista do segundo pós-guerra, devido à força normativa da Constituição, à inércia na execução das políticas públicas e à regulamentação deficiente dos direitos positivados pelo legislador. Para Streck (2011, p. 190), “o grau de intervenção da justiça constitucional dependerá do nível de concretização dos direitos estabelecidos na Constituição".

No Brasil, a judicialização "é um fato, uma circunstância que decorre do modelo constitucional que se adotou, e não um exercício deliberado de vontade política" (BARROSO, 2012a, p. 25). Assim, inegável a relação do constitucionalismo contemporâneo e das promessas constitucionais com a judicialização da política, principalmente porque a Constituição de 1988 trouxe a previsão textual da jurisdição constitucional que ampliou de maneira singular a importância e a atuação do Poder Judiciário na concretização de direitos.

Conforme já se pôde observar a judicialização da política é algo natural, inerente ao constitucionalismo contemporâneo, pois, justamente, se intensificou no período pós Segunda Guerra Mundial e com a constitucionalização dos direitos humanos. Nesse sentido, Streck no explica que sempre que tratamos do:

papel/função da Jurisdição Constitucional (ou do Poder Judiciário) na realização/efetivação de direitos sociais-fundamentais, é porque se está a admitir que, primeiro, há uma inefetividade da Constituição, e, segundo, em havendo inércia dos Poderes Públicos na realização/implementação de políticas públicas aptas à efetivação dos direitos sociais-fundamentais assegurados pela Lei Maior, é possível (e necessária) a intervenção da justiça constitucional (STRECK, 2003, p. 260-261).

Sempre que uma norma constitucional não é corretamente regulamentada, ou, quando há regulamentação mas esta não vem sendo devidamente aplicada, o Poder Judiciário estaria plenamente legitimado a agir, ou seja, a busca pela aplicabilidade dos direitos fundamentais na via judicial é perfeitamente possível quando os Poderes Legislativo e Executivo se omitem ou são inoperantes, mas em contraponto, quando há políticas públicas eficientes e quando as normas estão devidamente regulamentadas o Poder Judiciário deve se autoconter (BARROSO, 2012a).

Muito embora o Judiciário venha tomando um papel mais ativo apenas em face da inoperância dos demais poderes, evidente que o fenômeno da judicialização possui uma face 
positiva, mas também uma negativa. Na visão de Barroso (2012a, p. 27) a face positiva da judicialização encontra-se na oportunidade de o Judiciário suprir as necessidades da sociedade que não foram satisfeitas pelo Congresso Nacional ou pela Presidência da República. Já a face negativa está no fato de que uma maior atuação do Judiciário acaba expondo as dificuldades do Poder Legislativo, o que tende a prejudicar o Estado Democrático de Direito, pois "não há democracia sólida sem atividade política intensa e saudável, nem tampouco sem Congresso atuante e investido de credibilidade".

A judicialização se apresenta como uma "questão social", que independe da vontade do Judiciário, mas sim deriva "de uma série de fatores originalmente alheios à jurisdição", como o aumento da litigiosidade em decorrência da ineficiência do Estado em implementar os direitos, logo, uma "diminuição da judicialização não depende, portanto, apenas de medidas realizadas pelo Poder Judiciário, mas, sim, de uma plêiade de medidas que envolvem um comprometimento de todos os poderes constituídos" (TASSINARI, 2013, p. 32-33).

Por óbvio, a ampla constitucionalização de direitos, em conjunto com a inércia do Legislativo fomentou a busca da efetivação de direitos via Poder Judiciário, o que, se encontra totalmente respaldado pelo texto constitucional que ampliou as atribuições do Judiciário e positivou a jurisdição constitucional. Entretanto o Judiciário deve observar certos limites e evitar decisionismos para que a política não se torne um predador do Direito.

\subsection{Decisionismos e a crítica ao ativismo judicial}

Diversos autores consideram o ativismo judicial como algo natural, inerente à jurisdição constitucional, todavia, tal entendimento só colabora para que cada vez mais tenhamos decisões baseadas em critérios morais e pessoais do magistrado e não em uma correta aplicação dos preceitos constitucionais.

Nas palavras de Marcus Paulo Veríssimo (2008) o ativismo decorre, justamente, do amplo processo de judicialização instaurado pelo Constituinte de 1988, vejamos:

Trata-se do surgimento, no País, de um judiciário "ativista", que não se constrange em exercer competências de revisão cada vez mais amplas, quer incidentes sobre a política parlamentar (via controle de constitucionalidade, sobretudo), quer incidentes sobre as políticas de ação social do governo (por intermédio das competências de controle da administração pública, controle esse interpretado de forma cada vez mais larga nos dias atuais). (VERÍSSIMO, 2008, p. 409). 
Luís Roberto Barroso descreve ativismo como "uma atitude, a escolha de um modo específico e proativo de interpretar a Constituição, expandindo o seu sentido e alcance", o autor ainda se refere à ideia central do ativismo "está associada a uma participação mais ampla e intensa do Judiciário na concretização dos valores e fins constitucionais, com maior interferência no espaço de atuação dos outros dois Poderes" (BARROSO, 2012a, p. 25). Este entendimento mostra-se como um conformador para o imaginário jurídico, não diferenciando realmente jurisdição e ativismo, mas colaborando para que haja confusão entre estes, o que, colabora para a aceitação do ativismo como algo natural.

Em contraponto pertinente expor o entendimento trazido por Lenio Luiz Streck que pretende fazer uma real diferenciação entre ativismo judicial e judicialização, atentemos:

um juiz ou tribunal pratica ativismo quando decide a partir de argumentos de
política, de moral, enfim, quando o direito é substituído pelas convicções pessoais
de cada magistrado (ou de um conjunto de magistrados); já a judicialização é um
fenômeno que exsurge a partir da relação entre os poderes do Estado (pensemos,
aqui, no deslocamento do polo de tensão dos Poderes Executivo e Legislativo em
direção da justiça constitucional). (STRECK, 2011, p. 589, nota de rodapé 123).

A doutrina crítica busca diferenciar os fenômenos da judicialização e do ativismo, expondo claramente suas diferenças e demonstrando que a judicialização caracteriza-se por buscar a concretização da Constituição, "atribuindo às demandas respostas constitucionalmente adequadas", enquanto que o ativismo se define por ser um "controle que se faz a partir da vontade ou da consciência do intérprete não representando uma concretização do texto constitucional, mas sim, o seu desvirtuamento". (TASSINARI, 2013, p. 34).

Infelizmente, no Brasil, se têm um déficit de doutrina crítica e diversos autores populares no meio acadêmico limitam-se a comentar decisões judiciais ao invés de realmente doutrinar. Ferreira (2016 p. 23), afirma que o Brasil sofre de um "déficit hermenêuticoconstitucional" que afeta tanto o meio acadêmico, quanto o Poder Judiciário e a jurisdição constitucional, isto se dá, segundo o autor, pelo fato de nossos intérpretes do Direito estarem aprisionados ao ultrapassado "modelo liberal-individualista-patrimonialista" e suas teorias pragmáticas e concurseiras, onde a doutrina parece ter deixado de doutrinar e contentou-se em apenas comentar e repetir jurisprudência.

Essa cultura da doutrina que comenta jurisprudência tende a fomentar os decionismos discricionários e o protagonismo judicial, conforme se observa das palavras do então Ministro Humberto Gomes de Barros do Superior Tribunal de Justiça, que demonstra total desprezo 
pela doutrina e decide unicamente com sua consciência, corroborando para um avanço do ativismo no Judiciário brasileiro, vejamos:

\begin{abstract}
Não me importa o que pensam os doutrinadores. Enquanto for Ministro do Superior Tribunal de Justiça, assumo a autoridade da minha jurisdição. $O$ pensamento daqueles que não são Ministros deste Tribunal importa como orientação. A eles, porém, não me submeto. [...] Decido, porém, conforme minha consciência. Precisamos estabelecer nossa autonomia intelectual, para que este Tribunal seja respeitado. É preciso consolidar o entendimento de que os Srs. Ministros Francisco Peçanha Martins e Humberto Gomes de Barros decidem assim, porque pensam assim. E o STJ decide assim, porque a maioria de seus integrantes pensa como esses Ministros. Esse é o pensamento do Superior Tribunal de Justiça, e a doutrina que se amolde a ele. É fundamental expressarmos o que somos. Ninguém nos dá lições. Não somos aprendizes de ninguém.
\end{abstract}

Assim, percebe-se que a única maneira de lidar com juízes que acham que são Deuses, consideram que sabem tudo sobre tudo e não precisam de opiniões de doutrinadores é justamente doutrinar e ser persistente na crítica ao ativismo, pois este é o seu papel principal. Nas palavras de Streck (2015, p. 25) “o Direito não é (e não pode ser) aquilo que o intérprete quer que ele seja".

Ademais, a crítica ao ativismo judicial e ao protagonismo judicial vem sendo feita até mesmo pelo Legislativo, quando em 2015, dentre as alterações trazidas pelo Novo Código de Processo Civil o legislador acabou com o livre convencimento do juiz nas decisões, prevendo, agora, no art. 489 do CPC critérios que devem ser obedecidos pelo magistrado para uma correta fundamentação da sentença. Por certo, tal alteração legislativa visa coibir protagonismos e discricionariedades.

Tanto a judicialização da política, quanto o ativismo judicial recebem a crítica de que colocam em risco a legitimidade democrática, entretanto, este é o que mais parece pôr em risco o pacto democrático. Inicialmente a crítica no tocante ao problema democrático causado pela judicialização e pelo ativismo está no fato de que os juízes e desembargadores não são eleitos democraticamente e mesmo assim desempenham um poder político, aliás o Supremo Tribunal Federal desempenha um papel predominantemente contramajoritário, mas sempre pró-constituição.

Sobre tal argumento, temos que a atuação do Judiciário se encontra respaldada normativamente, já que a própria Constituição Federal atribui expressamente esse papel ao judiciário, bem como, filosoficamente, já que "a democracia não se resume ao princípio majoritário". (BARROSO, 2012a, p. 28)

Sendo que o principal objetivo da Constituição é o de salvaguardar "valores e direitos fundamentais, mesmo que contra a vontade circunstancial de quem tem mais votos", temos 
que "a jurisdição constitucional bem exercida é antes uma garantia para a democracia, do que um risco". (BARROSO, 2012a, p. 28). Logo, o problema democrático não está na judicialização, mas na discricionariedade do ativismo, onde o judiciário profere decisões baseadas em convicções pessoais do magistrado e não devidamente fundamentadas nos Princípios da Constituição.

Por óbvio o ativismo judicial tende a prejudicar a democracia, sobre isso, Streck (2015, p. 34) menciona que "em uma democracia e com uma Constituição compromissária como a brasileira, não é possível pensar a figura do juiz como 'acima das partes' ou o 'guardião-da-parte-que-falhou'”.

Em que pese o argumento recorrentemente evocado de que a concretização dos direitos através do judiciário enfraquece a cidadania e coloca em risco a própria democracia, Streck (2011, p.189) explica que embora haja tal argumento, "não há qualquer registro de que a democracia brasileira tenha sido colocada em xeque diante das decisões judiciais concessivas de direitos" (jurisprudência de valores ou ativismo judicial).

\section{A ATUAÇÃO POLÍTICA DO SUPREMO TRIBUNAL FEDERAL}

Ao julgar o mandado de injunção sobre a greve no serviço público ${ }^{46}$, no ano de 2007 , o Supremo Tribunal Federal ultrapassou a linha tênue entre Direito e Política, transformandose em um tribunal predominantemente político, ou seja, um tribunal mais preocupado em resolver as questões políticas do país, do que em defender a supremacia constitucional. O caráter político de tal decisão pode ser observado da simples análise do voto do Ministro Celso de Mello, que entende que o Judiciário não pode tolerar inércias do Poder Legislativo, vejamos:

não mais se pode tolerar, sob pena de fraudar-se a vontade da Constituição, esse estado de continuada, inaceitável, irrazoável e abusiva inércia do Congresso Nacional, cuja omissão, além de lesiva ao direito dos servidores públicos civis - a quem se vem negando, arbitrariamente, o exercício do direito de greve, já assegurado pelo texto constitucional -, traduz um incompreensível sentimento de desapreço pela autoridade, pelo valor e pelo alto significado de que se reveste a

\footnotetext{
46 A decisão foi tomada no julgamento dos Mandados de Injunção (MIs) 670, 708 e 712, ajuizados, respectivamente, pelo Sindicato dos Servidores Policiais Civis do Estado do Espírito Santo (SINDPOL), pelo Sindicato dos Trabalhadores em Educação do Município de João Pessoa (SINTEM) e pelo Sindicato dos Trabalhadores do Poder Judiciário do Estado do Pará (SINJEP). Os sindicatos buscavam assegurar o direito de greve para seus filiados e reclamavam da omissão legislativa do Congresso Nacional em regulamentar a matéria, conforme determina o artigo 37, inciso VII, da Constituição Federal.
} 
Constituição da República (STF. VOTO. MANDADO DE INJUNÇÃO n. ${ }^{\circ}$ 708-0 DF).

Em $2016^{47}$ tivemos diversas decisões do Supremo que deixaram claro seu caráter de Tribunal Político, vejamos algumas das decisões destacadas: a possibilidade de execução da pena após condenação em segunda instância, ou relativização da presunção de inocência (HC n. ${ }^{\circ} 126.292$ e ADC n. ${ }^{\circ} 43$ e n. $\left.{ }^{\circ} 44\right)$; a suspensão da posse de Luiz Inácio Lula da Silva como ministro chefe da Casa Civil (MS n. 34.070 e n. ${ }^{\circ}$ 34.071); a suspensão do mandato do Deputado Federal Eduardo Cunha (AC n. ${ }^{\circ}$ 4.070); o tráfico privilegiado, que deixou de ser considerado como um crime hediondo ( $\mathrm{HC}$ n. ${ }^{\circ}$ 118.533); o aborto até o terceiro mês de gestação foi descriminalizado ( $\mathrm{HC}$ n. ${ }^{\circ}$ 124.306); Renan Calheiros foi liminarmente afastado da presidência do Senado e depois apenas da linha sucessória da presidência da República (ADPF n. ${ }^{\circ}$ 402); o Projeto de Lei de Iniciativa Popular sobre as 10 medidas de combate à corrupção voltou à Câmara dos Deputados para reiniciar o seu trâmite (MS n. ${ }^{\circ}$ 34530).

Todos estes exemplos citados mostram-se como decisões estritamente políticas da Corte, onde os Ministros decidiram de acordo com interesses políticos, clamor popular e convicções pessoais dos julgadores, ou seja, agiram com claro decisionismo, implicando em decisões ativistas, que muitas vezes até contrariam disposições legais e constitucionais expressas.

De fato, uma maior autonomia do Poder Judiciário não pode implicar em uma atuação ativista por parte dos julgadores. As decisões do Supremo Tribunal Federal não podem estar justificadas no clamor das ruas, tampouco no interesse de partidos políticos, visto que o Supremo é um tribunal com caráter contramajoritário. O único parâmetro aceitável para as decisões judiciais são as normas constitucionais, qualquer julgamento fundamentado de modo é ativista, discricionário e contrário à democracia.

O Constitucionalismo Contemporâneo não permite nenhum tipo de discricionariedade, por certo, "conceder aos juízes o poder de livre atribuição sobre o Direito deve ser considerado uma postura autoritária, capaz de acarretar graves prejuízos ao regime democrático" (STRECK; TASSINARI; LIMA, 2013, p. 751). Assim como o Judiciário deve controlar a atuação dos Poderes Políticos, cabe à doutrina fazer o controle da atuação política do Judiciário, para tanto, é necessária uma maior defesa da autonomia do Direito frente às afrontas do poder Político, mesmo quando este poder vem do Judiciário.

\footnotetext{
${ }^{47}$ Feito com base no artigo "Retrospectiva 2016 - Os 10 julgamentos mais importantes do STF no ano, segundo o ministro Barroso", do site Consultor Jurídico - Conjur. Disponível em: <https://www.conjur.com.br/dl/retrospectiva-barroso-2016-parte.pdf>. Acesso em: 29 nov. 2017.
} 


\section{CONSIDERAÇÕES FINAIS}

Tendo em vistas os longos anos em que o Judiciário foi menosprezado e fragilizado diante dos demais poderes, nada mais natural que em face de uma Constituição de traz em seu corpo a previsão inédita de uma autêntica jurisdição constitucional, bem como de uma autonomia do Direito e do Poder Judiciário, os julgadores se sintam com uma maior liberdade, no sentido de atuar até mesmo de uma maneira mais política.

Entretanto, embora o Direito e a Política sejam conceitos interdependentes, há uma clara distinção entre ambos que precisa ser respeitada para que seja garantido o respeito ao Estado Democrático de Direito.

O Constitucionalismo Contemporâneo trouxe a possibilidade da judicialização da política, como sendo algo inerente à jurisdição constitucional, todavia, é necessário que os parâmetros e limites constitucionais sejam observados, sob pena de adentrarmos no problema do ativismo judicial, onde decisionismos discricionários se sobrepõem ao real sentido das normas constitucionais.

Por fim, constatou-se que nos últimos anos o Supremo Tribunal Federal assumiu um papel manifesto de Corte Política, decidindo sobre diversos aspectos de ordem social, econômica e política, todavia, em sua maioria as decisões não seguem uma fundamentação capaz de criar uma jurisprudência coerente. Nos últimos tempos, decisões do Supremo fundadas no clamor público e/ou social tem se tornado corriqueiras, o que demonstram que a atuação política deste Tribunal tem se mostrado muito mais ativista do que uma decisão de jurisdição constitucional.

$\mathrm{Na}$ medida em que decisões ativistas colocam em risco o pacto democrático e muitas vezes geram interpretações contrárias à dispositivos expressos na Constituição, fica clara a importância da doutrina crítica na tentativa de combater as discricionariedades, controlar política e hermeneuticamente os Poderes da União e garantir uma real autonomia do Direito.

\section{REFERÊNCIAS}

BARROSO, Luís Roberto. "Judicialização, ativismo judicial e legitimidade democrática". [Syn]Thesis. v.05. n.01. Rio de Janeiro: UERJ, p. 23-32, 2012a. 
O controle de constitucionalidade do direito brasileiro: exposição sistemática da doutrina e análise crítica da jurisprudência. 6. ed. rev. e atual. São Paulo: Saraiva, 2012b.

OSÓRIO, Aline. "Os dez temas mais importantes do STF em 2016". Consultor

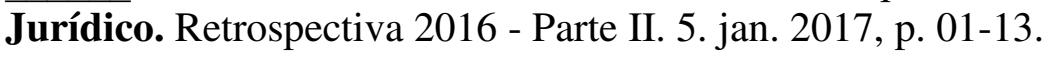

BRASIL. Constituição. Brasília: Senado Federal, 1988.

BRASIL. Supremo Tribunal Federal. Pesquisa de Jurisprudência. MI n. ${ }^{\circ}$ 708-0/DF. Mandado de Injunção. Disponível em: <http://www.stf.jus.br/portal/jurisprudencia/visualizarEmenta.asp?s1=000234216\&base=base Monocraticas>. Acesso em: 25 nov. 2017.

BRASIL. Superior Tribunal Federal. Voto - Ministro Humberto Gomes de Barros. AgRg nos EREsp 279889. Agravo Regimental nos Embargos de Divergência em Recurso Especial n. ${ }^{\circ}$ 279.889/AL. Julgado em 14 ago. 2002. Disponível em: <https://ww2.stj.jus.br/processo/pesquisa/?tipoPesquisa=tipoPesquisaNumeroRegistro\&termo $=200101540593 \&$ totalRegistrosPorPagina $=40 \&$ aplicacao $=$ processos.ea $>$. Acesso em: 29 jul. 2017.

FERREIRA, Rafael Fonseca. Internacionalização da Constituição. 1.ed. Porto Alegre: Lumen Juris, 2016.

HIRSCHL, Ran. "O novo constitucionalismo e a judicialização da política pura no mundo". Revista de Direito Administrativo. Editora FGV: Rio de Janeiro, v. 251, p. 139-178, maio/ago. 2009.

STRECK, Lenio Luiz. "Jurisdição Constitucional e Hermenêutica: Perspectivas e possibilidades de concretização dos Direitos Fundamentais-Sociais no Brasil". Novos Estudos Jurídicos. v.08. n.02. Itajaí: Fundação Universidade do Vale do Itajaí - Univali, p.257-301, 2003.

O que é isto - decido conforme a minha consciência? 5.ed. rev. e atual. Porto Alegre: Livraria do Advogado, 2015.

. Verdade e Consenso: Constituição, hermenêutica e teorias discursivas. 4. ed. São Paulo: Saraiva, 2011. 
; TASSINARI, Clarissa; LIMA, Danilo Pereira. "A relação direito e política: uma análise da atuação do Judiciário na história brasileira". Revista Pensar. Fortaleza, v. 18, n. 3, p. 737-758, set./dez. 2013.

TASSINARI. Clarissa. Jurisdição e Ativismo judicial: Limites da atuação do judiciário. 1. ed. Porto Alegre: Livraria do Advogado, 2013.

VERÍSSIMO, Marcus Paulo. “A Constituição de 1988, vinte anos depois: suprema corte e ativismo judicial 'à brasileira"'. Revista Direito GV. v.04, n.02, São Paulo: FGV, p.407-440, 2008.

\title{
THE POLITICAL ACTION OF THE SUPREME FEDERAL COURT: CONSTITUTIONAL JURISDICTION OR JUDICIAL ACTIVISM?
}

\begin{abstract}
Politics and Law, the political action that the Federal Supreme Court has had in recent times, observing aspects that can lead to verify if this action is is within the parameters of the constitutional jurisdiction or can be considered as an activist position of the judges. Among the specific objectives of the research, it is intended, at the outset, to approach the relationship of dissimilarity and dependence between Law and Politics, in order to verify how the Federal Constitution of 1988 and the constitutional jurisdiction changed this relationship. It is also intended to address the institutes of constitutional jurisdiction and judicial activism, establishing a distinction between the two so that it is possible to ascertain whether the political action of the Federal Supreme Court can be considered as a natural reflection of constitutional jurisdiction and of greater autonomy which the 1988 constituent granted to the Judiciary or is characterized as a discretionary action, typical of the institute of judicial activism. To that end, the methodological basis of this research is the phenomenological-hermeneutic, which goes beyond an exclusively semantic analysis of language, seeks to overcome the preconceptions of common sense, to make a historical reconstruction based on a critical theory.
\end{abstract}

Keywords: Political action. Constitutional Jurisdiction. Activism. Autonomy of Law 